\title{
PENGARUH STRUKTUR AKTIVA, STABILITAS PENJUALAN, DAN RETURN ON ASSETS TERHADAP DEBT TO EQUITY RATIO DENGAN UKURAN PERUSAHAAN SEBAGAI VARIABEL MODERATING PADA PT. BINTAN GAS JAYA SAKTI
}

\author{
Bambang Sambodo \\ Sekolah Tinggi Ilmu Ekonomi (STIE) Pembangunan Tanjungpinang \\ bambangsambodo@stie-pembangunan.ac.id \\ Rachmad Chartady \\ Sekolah Tinggi Ilmu Ekonomi (STIE) Pembangunan Tanjungpinang \\ chartady@stie-pembangunan.ac.id
}

\begin{abstract}
Abstrak: Tujuan dari penelitian ini adalah untuk mengetahui pengaruh dari struktur aktiva, stabilitas penjualan, dan return on assets terhadap debt to equity ratio dengan ukuran perusahaan sebagai variabel moderating Pada PT. Bintan Gas Jaya Sakti. Metode yang digunakan dalam penelitian ini adalah metode kuantitatif dan menggunakan data sekunder berupa laporan neraca dan laba rugi perbulan periode 2015-2018. Pengujian statistik dalam penelitian ini terdiri dari uji asumsi klasik, analisis regresi linear berganda, uji parsial (uji-t), Moderated Regression Analysis (MRA), serta koefisien determinasi $\left(\mathrm{R}^{2}\right)$. Hasil penelitian secara parsial dengan nilai $t_{\text {tabel }} 2,015$ menunjukkan bahwa Struktur Aktiva berpengaruh signifikan terhadap Debt to Equity Ratio dengan dengan thitung 6,800 dan nilai signifikan 0,000. Stabilitas Penjualan tidak berpengaruh signifikan terhadap Debt to Equity Ratio dengan nilai thitung $-1,383$ dan nilai sig 0,174. Return On Assets berpengaruh negatif dan signifikan terhadap Debt to Equity Ratio dengan nilai $t_{\text {hitung }}-2,771$ dan nilai sig 0,008. Ukuran Perusahaan berpengaruh terhadap Debt to Equity Ratio dengan nilai thitung 18,324 dan nilai sig 0,000. Ukuran Perusahaan merupakan variabel moderating yang mampu memperkuat hubungan antara Struktur Aktiva terhadap Debt to Equity Ratio. Namun Ukuran Perusahaan bukan merupakan variabel moderating yang mampu memperkuat atau memperlemah hubungan antara Stabilitas Penjualan terhadap Debt to Equity Ratio. Tetapi, Ukuran Perusahaan merupakan variabel moderating yang mampu memperkuat hubungan antara Return On Assets terhadap Debt to Equity Ratio. Berdasarkan hasil uji koefisien determinasi, nilai Adjusted R Square sebesar 0,885 atau 88,5\% sedangkan sisanya $11,5 \%$ dipengaruhi oleh variable lain yang tidak diteliti dalam penelitian ini.
\end{abstract}

Kata Kunci: Struktur Aktiva, Stabilitas Penjualan, Return On Assets, Debt To Equity Ratio, dan

Ukuran Perusahaan.

Abstract: The purpose of this research is to know the effect of assets structure, sales, and return on assets for debt to equity ratio with the company size as moderating variables in. Bintan Gas Jaya Sakti. The method used in this study is a quantitative method and uses secondary data consisting of the monthly allocation and income statement for the 2015-2018 period. Statistical testing in this study consists of the classical assumption test, multiple linear regression analysis, partial test ( $t$ test), Moderated Regression Analysis (MRA), and the coefficient of determination $\left(R^{2}\right)$. The partial results of the study with a value of $t_{\text {table }} 2,015$ showed a significant Asset Structure to the Debt to Equity Ratio with a $t_{\text {count }}$ of 6,800 and a significant value of 0,000. Sales Stability is insignificant to the Debt to Equity Ratio with a $t_{\text {count }}$ of -1.383 and a sig value of 0.174. Return On Assets is negative and significant towards the Debt to Equity Ratio with a value of table $-2,771$ and a sig value of 0.008. The value of the Company evaluates the Debt to Equity Ratio with a $t_{\text {count }}$ of 18,324 and a sig of 0,000 Company size is a moderating variable that is supported by the relationship between the Structure of Assets to Debt to Equity Ratio. However, company size is not a moderating variable that supports or weakens the relationship between Sales Stability to Debt to Equity Ratio. However, company size is a moderating variable that can support the relationship between Return On Assets and Debt to Equity Ratio. Based on the results of the coefficient of determination test, the Adjusted $R$ Square 
value of 0.885 or $88.5 \%$ while the remaining $11.5 \%$ is needed by other variables not approved in this study. An abstract is a brief summary of a research article, thesis, review, conference proceeding or any-depth analysis of a particular subject or disipline, and is often used to help the reader quickly ascertain the paper purposes. When used, an abstract always appears at the beginning of a manuscript or typescript, acting as the point-of-entry for any given academic paper or patent application. Absatrcting and indexing services for various academic discipline are aimed at compiling a body of literature for that particular subject. Abstract length varies by discipline and publisher requirements. Abstracts are typically sectioned logically as an overview of what appears in the paper.

Keywords: Asset Structure, Sales Stability, Return On Assets, Debt to Equity Ratio, and Company Size.

\section{PENDAHULUAN}

Pada zaman sekarang ini karakteristik dunia usaha berkembang dengan sangat pesat di segala bidang. Dengan pesatnya perkembangan tersebut dapat menimbulkan persaingan yang ketat antar perusahaan, sehingga perusahaan akan melakukan berbagai aktivitas untuk mencapai tujuannya. Bagi pihak manajemen, dituntut untuk dapat mengkoordinasikan penggunaan seluruh sumber daya yang dimiliki oleh perusahaan secara efesien dan efektif salah satunya yaitu keputusan pendanaan untuk mendanai perusahaan, serta memilih alternatif investasi yang tepat dengan menggunakan modal yang dimiliki oleh perusahaan tersebut. Pada dasarnya, jika perusahaan meningkatkan jumlah utang sebagai sumber dana, hal tersebut dapat meningkatkan resiko keuangan. Jika perusahaan tidak dapat mengelola dana yang diperoleh dari utang secara produktif, hal tersebut akan memberikan pengaruh yang negatif dan berdampak pada perusahaan, begitu pula sebaliknya.
Struktur modal merupakan perbandingan antara modal sendiri dengan pinjaman jangka panjang. Besar kecilnya rasio ini menunjukkan banyak ataupun sedikitnya jumlah pinjaman jangka panjang dari pada modal sendiri. Ada beberapa rasio yang digunakan untuk mengukur struktur modal salah satu rasio dari struktur modal yaitu Debt to Equity Ratio.

Debt to Equity Ratio yang disebut juga dengan rasio utang terhadap ekuitas dapat digunakan untuk mengetahui besarnya proporsi antara ekuitas dan utang yang digunakan oleh perusahaan. Debt to Equity Ratio ini digunakan untuk mengukur kemampuan perusahaan dalam melunasi kewajibannya. Debt to Equity Ratio ini sangat penting untuk memeriksa kesehatan keuangan perusahaan. Jika rasio ini meningkat, artinya perusahaan dibiayai oleh kredito (pemberi utang) dan bukan dari sumber keuangannya sendiri. Struktur aktiva merupakan kekayaan yang dimiliki perusahaan dan diharapkan bisa memberikan manfaat dimasa yang akan datang. Komposisi aktiva yang dapat dijadikan jaminan 
perusahaan akan mempengaruhi pembiayaan dan seorang investor akan lebih mudah memberikan pijaman bila disertai dengan jaminan yang ada.

Stabilitas penjualan merupakan salah satu yang mempengaruhi struktur modal. Stabilitas penjualan menggambarkan tingkat kesbtabilan penjualan dalam suatu perusahaan. Perusahaan dengan penjualan yang relaitf stabil dapat lebih aman memperoleh lebih banyak pinjaman dan menanggung beban tetap yang lebih tinggi dibandingkan dengan perusahaan yang tingkat penjualannya tidak stabil. Return On Asset merupakan rasio yang menunjukkan kemampuan perusahaan dalam memperoleh laba dengan pemanfaatan aktiva yang ditanamkan pada perusahaan. Salah satu alasan perusahaan dengan profit yang tinggi lebih mengarahkan pada utang dengan harapan manajer akan lebih disiplin dalam penggunaan dana perusahaan. Ukuran perusahaan dapat diketahui untuk menilai ukuran besar atau kecilnya perusahaan. Besar kecilnya ukuran perusahaan sangat mempengaruhi keputusan manajemen dalam menjalankan kegiatan operasionalnya. Ukuran perusahaan bisa dilihat pada aset yang dimiliki perusahaan. Semakin besar ukuran perusahaan, maka semakin besar dana yang dimiliki perusahaan.

PT. Bintan Gas Jaya Sakti adalah perusahaan dagang yang bergerak dibidang pendistribusian gas Elpiji $3 \mathrm{~kg}$. PT. Bintan Gas Jaya Sakti berlokasi di Jl. Raya Tg. Uban
RT 02 RW 01 Dusun Toapaya, Bintan. Perusahaan ini termasuk dalam perusahaan dagang dimana persediaannya merupakan asset utama dalam keberlangsungannya dalam hal penjualan gas elpiji.

Berdasarkan laporan keuangan pada PT. Bintan Gas Jaya Sakti menunjukkan hasil naik turunnya data keuangan PT. Bintan Gas Jaya Sakti. Berikut nilai Struktur Aktiva, Stabilitas penjualan, Return On Assets, dan Debt to Equity Ratio dan Ukuran Perusahaan pada laporan PT. Bintan Gas Jaya Sakti pada tahun 2018 terdapat beberapa variasi masalah yang terjadi pada perusahaan tersebut, yaitu perubahan pada nilai utang yang terjadi pada tahun tersebut. Terlihat bahwa nilai debt to equity ratio terus mengalami peningkatan dari bulan Agustus, September, dan November. Pada bulan November nilai debt to equity ratio mengalami peningkatan sebesar 0,024 menjadi 0,639. Kenaikan tersebut merupakan kenaikan tertinggi yang terjadi pada 2018. Namun peningkatan ini tidak diikuti peningkatan sturktur aktiva yang mengalami penurunan sebesar 0,652 , stabilitas penjualan sebesar -0,142 dan return on asset sebesar 0,011. Namun untuk ukuran perusahaan mengalami peningkatan menjadi sebesar 20,597 .

Berdasarkan latar belakang masalah diatas, maka penulis tertarik untuk membahas permasalahan tersebut dengan mengambil judul penelitian "Pengaruh Struktur Aktiva, Stabilitas Penjualan, dan Return On Assets Terhadap Debt To Equity Ratio 
Dengan Ukuran Perusahaan Sebagai Variabel Moderating Pada PT. Bintan Gas Jaya Sakti”.

Rumusan masalah dalam penelitian ini adalah : (1) Apakah stuktur aktiva berpengaruh terhadap Debt to Equity Ratio pada PT. Bintan Gas Jaya Sakti? (2) Apakah stabilitas penjualan berpengaruh terhadap Debt to Equity Ratio pada PT. Bintan Gas Jaya Sakti? (3) Apakah Return on Assets berpengaruh terhadap Debt to Equity Ratio pada PT. Bintan Gas Jaya Sakti? (4) Apakah Ukuran Perusahaan berpengaruh terhadap Debt to Equity Ratio pada PT. Bintan Gas Jaya Sakti? (5) Apakah Ukuran Perusahaan sebagai variabel moderating dapat memoderasi hubungan antara Strtuktur Aktiva terhadap Debt to Equity Ratio pada PT. Bintan Gas Jaya Sakti? (6) Apakah Ukuran Perusahaan sebagai variabel moderating dapat memoderasi hubungan antara stabilitas penualan terhadap Debt to Equity Ratio pada PT. Bintan Gas Jaya Sakti? (7) Apakah Ukuran Perusahaan sebagai variabel moderating dapat memoderasi hubungan antara Return On Assets terhadap Debt to Equity Ratio pada PT. Bintan Gas Jaya Sakti?

Tujuan dalam penelitian ini adalah (1) Untuk mengetahui apakah Stuktur Aktiva berpengaruh terhadap Debt to Equity Ratio pada PT. Bintan Gas Jaya Sakti. (2) Untuk mengetahui apakah Stabilitas Penjualan berpengaruh terhadap Debt to Equity Ratio pada PT. Bintan Gas Jaya Sakti. (3) Untuk mengetahui apakah Return on Assets berpengaruh terhadap Debt to Equity Ratio pada PT. Bintan Gas Jaya Sakti. (4) Untuk mengetahui apakah Ukuran Perusanaan berpengaruh terhadap Debt to Equity Ratio pada PT. Bintan Gas Jaya Sakti. (5) Untuk mengetahui apakah Ukuran Perusahaan sebagai variabel moderating dapat memoderasi hubungan antara Strtuktur Aktiva terhadap Debt to Equity Ratio pada PT. Bintan Gas Jaya Sakti. (6) Untuk mengetahui apakah Ukuran Perusahaan sebagai variabel moderating dapat memoderasi hubungan antara stabilitas penualan terhadap Debt to Equity Ratio pada PT. Bintan Gas Jaya Sakti. (7) Untuk mengetahui apakah Ukuran Perusahaan sebagai variabel moderating dapat memoderasi hubungan antara Return On Assets terhadap Debt to Equity Ratio pada PT. Bintan Gas Jaya Sakti.

Dalam penelitian ini pula diharapkan penelitian ini dapat berguna untuk kegunaan ilmiah dan kegunaan praktis. Kegunaan ilmiah dari hasil penelitian ini diharapkan bisa menjadi referensi yang dapat memberikan pengetahuan serta manfaat untuk peneliti dimasa yang akan datang dan menjadi kajian penelitian selanjutnya yang lebih mendalam khususnya dalam penelitian yang menggunakan ukuran perusahaan sebagai variabel moderating. Sedangkan kegunaan praktis dari penelitian ini diharapkan dapat berguna bagi perusahaan sebagai gambaran 
kondisi perusahaan yang bersangkutan dan berguna untuk penelitiannya.

\section{TINJAUAN PUSTAKA}

Tinjauan pustaka dalam penelitian ini terdiri dari :

Tinjauan Teori

\section{Debt to Equity Ratio}

Menurut (Kasmir, 2015:157) Debt to Equity Ratio merupakan rasio yang digunakan untuk menilai utang dengan ekuitas. Rasio ini dicari dengan cara membandingkan antara seluruh utang, termasuk utang lancar dengan seluruh ekuitas. Semakin kecil DER semakin baik karena jaminan terhadap utang lebih besar. Semakin besar DER menandakan struktur permodalan usaha lebih banyak memanfaatkan utang relative terhadap ekuitas (modal sendiri) dan mencerminkan resiko perusahaan yang relative tinggi.

\section{Struktur Aktiva}

Menurut (Syamsuddin, 2011:9) Struktur aktiva adalah penentuan berapa besarnya alokasi untuk masing-masing komponen aktiva, baik aktiva lancar maupun aktiva tetap. Struktur aktiva juga merupaka penentu besarnya alokasi dana untuk masing-masing komponen aktiva, baik dalam aktiva lancar maupun aktiva tetap. Semakin tinggi struktur aktiva perusahaaan, menunjukkan semakin tinggi kemampuan dari perusahaan tersebut untuk dapat menjamin hutang jangka panjang yang dipinjamnya.
3. Stabilitas Penjualan

Menurut (Musthafa, 2017:86) stabilitas penjualan adalah apabila penjualan perusahaan stabil meningkat, maka perusahaan dengan sendirinya memperoleh dana yang cukup besar, sehingga perusahaan akan mengurangi utangnya, bahkan bisa tidak menggunakan utang dalam operasi perusahaa. Tetapi sebaliknya, apabila penjualan perusahaan stabil menurun, maka akan berkurang dana perusahaan yang diperoleh, sehingga perusahaan akan menambah utang untuk keperluan operasi perusahaan.

\section{Return On Assets}

Menurut (Hery, 2015:228) rasio return on asset (ROA) adalah rasio yang menunjukkan seberapa besar kontribusi asset dalam menciptakan laba bersih. Rasio ini digunakan untuk mengukur seberapa besar jumlah laba yang dihasilkan oleh setiap rupiah yang tertanam dalam total asset perusahaan.

\section{Ukuran Perusahaan}

Ukuran Perusahaan merupakan nilai yang menunjukkan besar kecilnya perusahaan. Besar kecilya ukuran perusahaan diukur dengan menggunakan total penjualan, total aset, dan kapitalisasi pasar. Menurut (Sartono, 2010:249) perusahaan yang sudah well-established akan lebih mudah memperoleh modal di pasar modal jika di bandingkan dengan perusaahaan yang kecil.

\section{Kerangka Pemikiran}



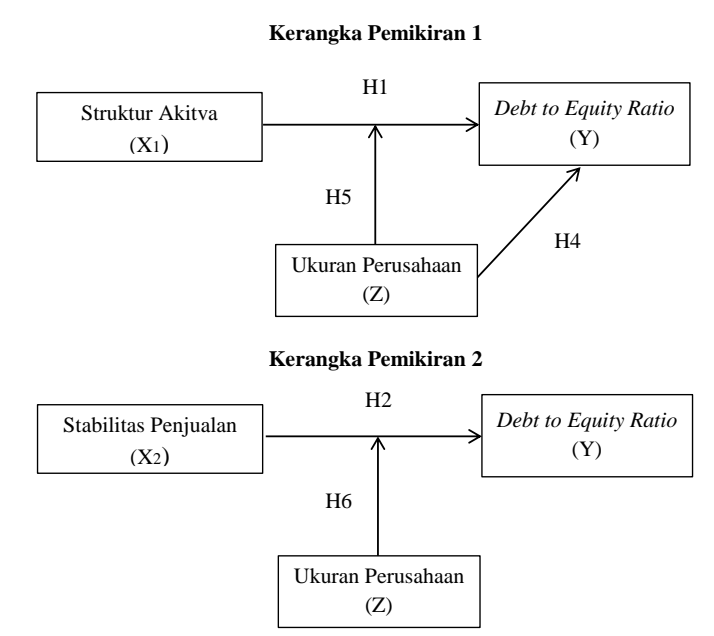

Kerangka Pemikiran 3

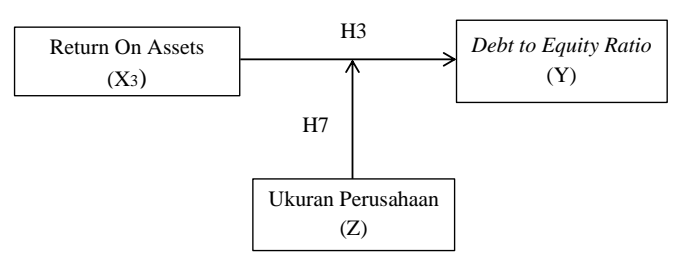

Sumber : (Nisfianti, 2017)

Keterangan :

$$
-\quad=\text { Pengujian secara parsial }
$$

\section{METODE PENELITIAN}

Dalam menyusun skripsi ini penulis menggunakan metode deskriptif kuantitatif. Data yang akan digunakan dalam penelitian ini merupakan data sekunder. Di dalam penelitian ini, data sekunder yang peneliti gunakan adalah laporan keuangan PT Bintan Gas Jaya Sakti, yaitu Laporan Laba Rugi dan Neraca dalam waktu 4 tahun selama periode 2015 sampai dengan 2018 dalam bentuk laporan bulanan berjumlah 48 data. Adapun metode pengumpulan data dalam penelitian ini adalah: Observasi, Studi Pustaka, dan Dokumentasi.
Dalam penelitian ini, definisi operasional variabel dan teknik pengolahan data adalah sebagai berikut:

Variabel Independen (X)

1. Struktur Aktiva adalah gambaran perbandingan antara aktiva tetap dengan total aktiva untuk mengetahui seberapa besar aset tetap perusahaan tersebut untuk dapat digunakan sebagai jaminan utang perusahaan. Struktur aktiva diukur dengan membandingkan antara aktiva dengan total aktiva perusahaan tersebut. Untuk memperoleh angka struktur aktiva, dapat digunakan rumus dibawah ini:

$$
\text { Struktur Aktiva }=\frac{\text { Aktiva Tetap }}{\text { Total Aktiva }}
$$

Sumber : (Syamsuddin, 2009:9) dalam (Batubara, Topowijono, \& Z. A., 2015)

2. Stabilitas penjualan adalah perubahan tingkat total penjualan tiap satu periode siklus akuntansi untuk mengukur penjualan pada suatu perusahaan. Stabilitas penjualan dapat diukur dengan melihat perbandingan antara jumlah penjualan bersih tahun bersangkutan dikurangi penjualan bersih tahun sebelumnya. Untuk memperoleh angka stabilitas penjualan, dapat digunakan rumus dibawah ini:

Stabilitas Penjualan $=\frac{\text { Total Penjualan }_{t}-\text { Total Penjualan }_{1-t}}{\text { Total Penjualan }_{1-t}}$

Sumber : Agus Sartono dalam (Suweta, 2016)

3. Return On Assets adalah rasio yang digunakan untuk mengukur kemampuan 
perusahaan dalam memanfaatkan keseluruhan aktiva yang digunakan untuk menghasilkan laba. Untuk memperoleh angka Return On Assets, dapat digunakan rumus dibawah ini:

Return On Assets $(R O A)=\frac{\text { LabaBersin }}{\text { Total Aset }}$

Sumber : (Hery, 2015:228)

Variabel Dependen (Y)

\section{Debt to Equity Ratio}

Struktur modal adalah gambaran pendanaan perusahaan yang terdiri dari utang jangka panjang dan modal sendiri yang digunakan untuk memenuhi kebutuhan perusahaan. Dalam penelitian ini struktur modal dihitung dengan menggunakan Debt to Equity Ratio (DER), dengan membandingkan antara total utang dan total modal yang terdapat pada laporan neraca perusahaan tersebut. Untuk memperoleh angka Debt to Equity Ratio, dapat digunakan rumus dibawah ini:

Debt Equity Ratio (DER) $=\frac{\text { Total Utang }}{\text { Total Modal }}$

Sumber : (Hery, 2015:198)

Variabel Moderating (Z)

1. Ukuran Perusahaan

Ukuran perusahaan merupakan nilai yang menggambarkan besarnya suatu perusahaan yang diukur berdasarkan besarnya aset (total aktiva) yang dimiliki oleh perusahaan. Pada penelitian ini, ukuran perusahaan diproksikan dengan menggunakan natural logaritma (ln) dari total aset yang diperoleh dari laporan neraca perusahaan tersebut. Untuk memperoleh angka ukuran perusahaan, dapat digunakan rumus dibawah ini:

Size $=\operatorname{Ln}($ Total Asset $)$

Sumber: Weston J. Fred dan Thomas dalam (Siti Nurlaela, 2017)

Alat analisis data yang digunakan dalam penelitian ini adalah dengan menggunakan program computer SPSS (Statistical Program For Social Science) versi 22.0 for windows. Adapun langkah-langkah teknik analisis data yang dapat digunakan diantaranya adalah sebagai berikut:

1. Uji Asumsi Klasik
a. Uji Normalitas
b. Uji Multikolinearitas
c. Uji Auto Korelasi
d. Uji Heteroskedastisitas

2. Uji Hipotesis
a. Moderated Regression Analysis (MRA)

b. Analisis Regresi Linear Berganda (a) Uji Parsial (Uji t)

3. Koefisien Determinasi $\left(\mathrm{R}^{2}\right)$ 
HASIL DAN PEMBAHASAN

\section{Analisis Data}

\section{Hasil Uji Statistik Deskriptif}

Tabel 1

Hasil Uji Statistik Deskriptif

\begin{tabular}{|l|r|r|r|r|r|}
\hline & N & Minimum & Maximum & Mean & $\begin{array}{c}\text { Std. } \\
\text { Deviation }\end{array}$ \\
\hline Struktur Aktiva & 48 &, 62 &, 74 &, 6842 &, 03072 \\
Stabilitas & 48 &,- 19 &, 21 &, 0115 &, 10729 \\
Penjualan & 48 &, 01 &, 04 &, 0229 &, 00967 \\
Return On Asset & 48 &, 36 &, 66 &, 5121 &, 08930 \\
Debt to Equity & & & & & \\
Ratio & 48 & 20,30 & 20,61 & 20,4879 &, 09365 \\
Ukuran & 48 & & & & \\
Perusahaan & & & & \\
Valid N (listwise) & & &
\end{tabular}

Sumber: Output SPSS Versi 22 Tahun 2019

Berdasarkan tabel diatas, dapat dijelaskan:

1. Struktur Aktiva memiliki jumlah data $(\mathrm{N})$ sebanyak 48 , dengan nilai minimum 0,62 , nilai maximum 0,74 , mean 0,6842 dan standard deviasi 0,03072.

2. Stabilitas penjualan memiliki jumlah data (N) sebanyak 48, dengan nilai minimum 0,19 , nilai maximum 0,21 , mean 0,0115 dan standard deviasi 0,10729.

3. Return On Assets memiliki jumlah data (N) sebanyak 48, dengan nilai minimum 0,01 , nilai maximum 0,04 , mean 0,0229 dan standard deviasi 0,00967.

4. Debt to Equity Ratio memiliki jumlah sampel (N) sebanyak 48, dengan nilai minimum 0,36 , nilai maximum 0,66 , mean 0,08930 dan standard deviasi 0,5121.

5. Ukuran perusahaan memiliki jumlah sampel (N) sebanyak 48, dengan nilai minimum 20,30, nilai maximum 20,61, mean 20,4879 dan standard deviasi 0,09365 .

\section{Hasil Uji Asumsi Klasik}

a. Uji Normalitas

Gambar 1

Grafik Histogram

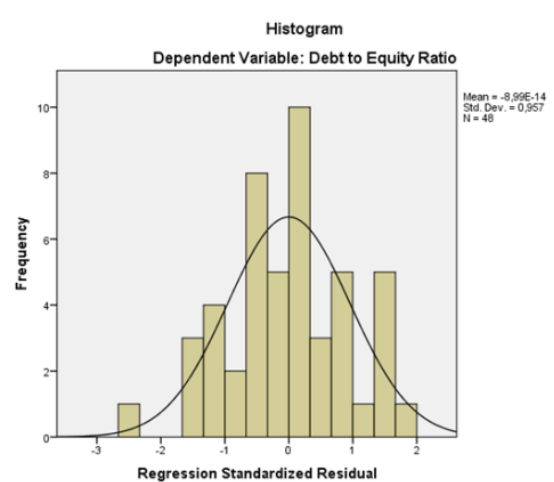

Sumber : Output SPSS Versi 22 Tahun 2019

Gambar 2

Hasil Uji Normalitas (Probability Plot)

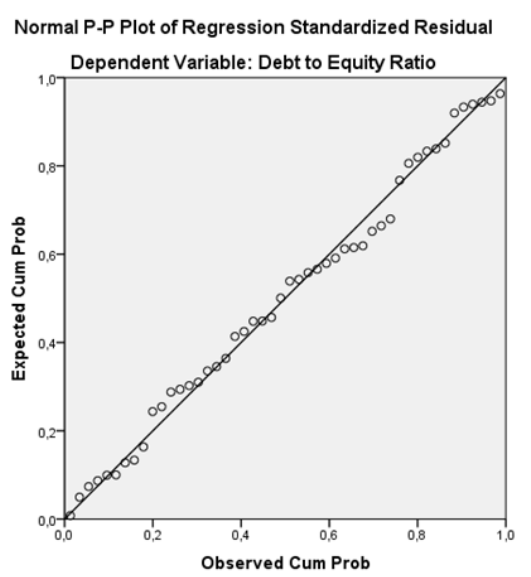

Sumber : Output SPSS Versi 22 Tahun 2019

Dari gambar 1 diatas dilihat bahwa grafik memberikan pola distibusi data yang normal. Sedangkan gambar 2 grafik normal probability plot terlihat bahwa titik-titik menyebar mengikuti garis diagonal dan menyebar disekitar garis diagonal. Hal ini menunjukkan bahwa pola dari grafik berdistribusi secara normal, maka model regresi memenuhi asumsi normal dan dapat dilanjutkan ke uji regresi lainya. 
Tabel 2

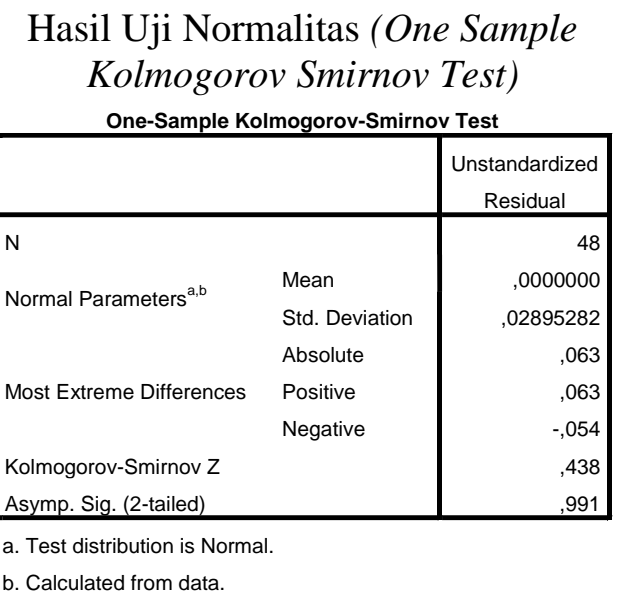

Sumber : Output SPSS Versi 22 Tahun 2019

Pada tabel di atas menunjukkan bahwa nilai Asymp. Sig (2-tailde) jika nilai sig > 0,05 maka data tersebut berdistribusi normal. Berdasarkan output One Sample Kolmogorov Smirnov Test pada tabel 2 terlihat bahwa asymp. Sig (2-tailed) sebesar 0,991>0,05. Artinya nilai residual terstandarisasi dinyatakan menyebar secara normal.

b. Uji Multikolinearitas

\section{Tabel 3}

Hasil Uji Multikolinearitas

\begin{tabular}{|c|c|c|c|c|c|c|c|}
\hline \multicolumn{8}{|c|}{ Coefficients $^{a}$} \\
\hline \multirow{2}{*}{ Model } & \multicolumn{2}{|c|}{$\begin{array}{c}\text { Unstandardized } \\
\text { Coefficients }\end{array}$} & \multirow{2}{*}{$\begin{array}{c}\begin{array}{c}\text { Standar } \\
\text { dized } \\
\text { Coeffici } \\
\text { ents }\end{array} \\
\text { Beta }\end{array}$} & \multirow{2}{*}{$\mathrm{t}$} & \multirow{2}{*}{ Sig. } & \multicolumn{2}{|c|}{$\begin{array}{l}\text { Collinearity } \\
\text { Statistics }\end{array}$} \\
\hline & B & $\begin{array}{l}\text { Std. } \\
\text { Error }\end{array}$ & & & & $\begin{array}{c}\text { Toleran } \\
\text { ce }\end{array}$ & VIF \\
\hline (Constant) & $-18,461$ & 1,014 & & $-18,201$ & , 000 & & \\
\hline $\begin{array}{l}\text { Struktur } \\
\text { Aktiva }\end{array}$ & 1,028 & ,151 & 354 & 6,800 & ,000 & ,904 & 1,106 \\
\hline $\begin{array}{ll}\text { Stabilitas } \\
1 \text { Penjualan }\end{array}$ &,- 058 & ,042 &,- 070 & $-1,383$ & ,174 & ,958 & 1,044 \\
\hline $\begin{array}{l}\text { Return On } \\
\text { Asset }\end{array}$ & $-1,372$ & , 495 &,- 149 & $-2,771$ & ,008 & ,851 & 1,175 \\
\hline $\begin{array}{l}\text { Ukuran } \\
\text { Perusahaan }\end{array}$ & 893 & ,049 & 937 & 18,324 & ,000 & ,935 & 1,069 \\
\hline
\end{tabular}

Sumber : Output SPSS Versi 22 Tahun 2019

Dari tabel diatas, dapat dilihat bahwa nilai tolerance Struktur Aktiva sebesar 0,904 > 0,1 dan nilai VIF Struktur Aktiva sebesar 1,106 <
10, Stabilitas Penjualan sebesar 0,958 > 0,1 dan nilai VIF Stabilitas Penjualan sebesar $1,044<10$, ROA sebesar $0,851>0,1$ dan nilai VIF ROA sebesar $1,175<10$ Dan nilai tolerance Ukuran Perusahaan adalah sebesar $0,935>0,1$ dan nilai VIF Ukuran Perusahaan sebesar $1,069<10$ sehingga dapat disimpulkan bahwa tidak terjadi multikolinearitas.

c. Uji Autokorelasi

Tabel 4

Hasil Uji Autokorelasi

\begin{tabular}{|l|r|r|r|r|r|}
\hline Model & $\mathrm{R}$ & $\begin{array}{c}\mathrm{R} \\
\text { Square }\end{array}$ & $\begin{array}{c}\text { Adjusted R } \\
\text { Square }\end{array}$ & $\begin{array}{r}\text { Std. Error of } \\
\text { the Estimate }\end{array}$ & $\begin{array}{r}\text { Durbin- } \\
\text { Watson }\end{array}$ \\
\hline 1 &, $946^{\mathrm{a}}$ &, 895 &, 885 &, 03027 & 1,011 \\
\hline
\end{tabular}
a. Predictors: (Constant), Ukuran Perusahaan, Stabilitas Penjualan,
Struktur Aktiva, Return On Asset
b. Dependent Variable: Debt to Equity Ratio

Dapat dilihat pada tabel diatas, nilai DW yang diperoleh adalah sebesar 1,011. Pada nilai 1,011 merupakan angka yang tidak lebih kecil dari -2, dan tidak lebih besar dari 2 (-2 $\leq$ $1,011 \leq 2)$. Sehingga dapat disimpulkan bahwa model regresi ini tidak terjadi autokorelasi.

d. Uji Heteroskedastisitas

Gambar 3

Hasil Uji Heteroskedastisitas (Metode Gambar Scatterplots Plot)

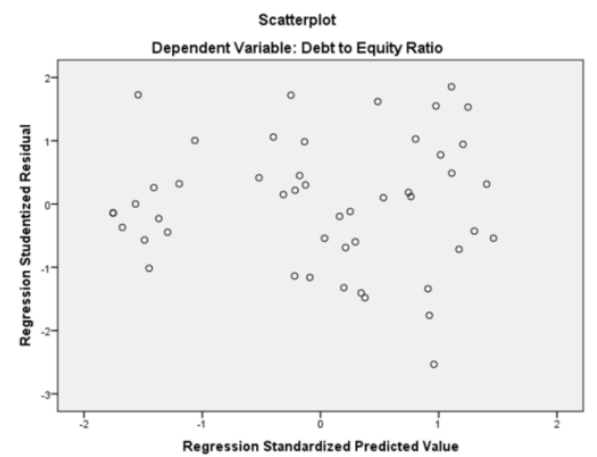

Sumber : Output SPSS Versi 22 Tahun 2019 
Dapat dilihat pada gambar diatas, menunjukkan titik-titik menyebar sevara acak dan tidak membentuk suatu pola tertentu dan titik-titik tersebut juga menyebar diatas dan dibawah angka 0 pada sumbu Y. Maka, dapat disimpulkan bahwa model regresi tidak terjadi heteroskedastisitas.

\section{Hasil Analisis Regresi Linear Berganda}

Analisis regresi linear berganda digunakan untuk melihat ada atau tidaknya pengaruh atau hubungan secara linear antara dua variabel atau lebih variabel independen dengan satu variabel dependen. Hasil outuput analisis regresi linear berganda dapat dilihat pada tabel berikut ini:

Tabel 5

Hasil Analisis Regresi Linear Berganda

\begin{tabular}{|c|c|c|c|c|c|}
\hline \multicolumn{6}{|c|}{ Coefficients $^{a}$} \\
\hline \multirow[t]{2}{*}{ Model } & \multicolumn{2}{|c|}{$\begin{array}{c}\text { Unstandardized } \\
\text { Coefficients }\end{array}$} & \multirow{2}{*}{$\begin{array}{c}\text { Standardized } \\
\text { Coefficients }\end{array}$} & \multirow[t]{2}{*}{$\mathrm{t}$} & \multirow[t]{2}{*}{ Sig. } \\
\hline & B & $\begin{array}{l}\text { Std. } \\
\text { Error }\end{array}$ & & & \\
\hline (Constant) & $-18,461$ & 1,014 & & $-18,201$ &, 000 \\
\hline Struktur & 1,028 & ,151 & ,354 & 6,800 & ,000 \\
\hline Stabilitas & & & & & \\
\hline 1 Penjualan &,- 058 & ,042 &,- 070 & $-1,383$ & ,174 \\
\hline $\begin{array}{l}\text { Return On } \\
\text { Asset }\end{array}$ & $-1,372$ & ,495 &,- 149 & $-2,771$ &, 008 \\
\hline $\begin{array}{l}\text { Ukuran } \\
\text { Perusahaan }\end{array}$ & ,893 & ,049 & ,937 & 18,324 &, 000 \\
\hline
\end{tabular}

Sumber : Output SPSS Versi 22 Tahun 2019

Persamaan regresi linear berganda yang diperoleh dari tabel 6 diatas adalah sebagai berikut:

$$
\begin{aligned}
Y= & a+b_{1} X_{1}+b_{2} X_{2}+b_{3} X_{3}+b_{4} Z+e \\
Y= & -18,461+1,028 X_{1}-0,058 X_{2}-1,372 X_{3} \\
& +0,893 Z+e
\end{aligned}
$$

Persamaan regresi dapat dijelaskan sebagai berikut:

1. Konstanta (a) mempunyai nilai sebesar 18,461 dapat diartikan apabila nilai variabel independen yaitu Struktur Aktiva, Stabilitas Penjualan, Return On Asset, dan Ukuran Perusahaan adalah 0, maka Debt to Equity Ratio sebesar -18,461.

2. Koefisien regresi variabel Struktur Aktiva mempunyai nilai positif yaitu sebesar 1,028, dapat diartikan bahwa setiap peningkatan Struktur Aktiva sebesar 1 satuan, maka Debt to Equity Ratio juga akan meningkat sebesar 1,028 dengan asumsi variabel lain bernilai tetap.

3. Koefisien regresi variabel stabilitas penjualan mempunyai nilai negatif sebesar $-0,058$, dapat diartikan bahwa setiap peningkatan stabilitas penjualan sebesar 1 satuan, maka Debt to Equity Ratio akan mengalami penurunan sebesar $-0,058$ dengan asumsi variabel lain bernilai tetap.

4. Koefisien regresi variabel Return On Asset mempunyai nilai negatif yaitu sebesar 1,372 yang dapat diartikan bahwa setiap peningkatan return on asset sebesar 1 satuan, maka Debt to Equity Ratio akan mengalami penurunan sebesar $-1,372$ dengan asumsi bahwa variabel lain bernilai tetap.

5. Koefisien regresi variabel Ukuran perusahaan mempunyai nilai positif 0,893 dengan asumsi variabel lain bernilai tetap, 
yang artinya bahwa setiap peningkatan sebesar 1 satuan maka Debt to Equity Ratio akan mengalami peningkatan sebesar 0,893 .

a. Uji Koefisien Regresi secara Parsial(Uji t) Tabel 6

Hasil Uji Hipotesis Parsial (Uji T)

\begin{tabular}{|c|c|c|c|c|c|}
\hline \multirow{3}{*}{ Model } & \multicolumn{3}{|c|}{ Coefficients $^{\mathrm{a}}$} & \multirow{3}{*}{$t$} & \multirow{3}{*}{ Sig. } \\
\hline & $\begin{array}{r}\text { Unstand } \\
\text { Coeffic }\end{array}$ & Coefficients & $\begin{array}{l}\text { Standardized } \\
\text { Coefficients }\end{array}$ & & \\
\hline & B & $\begin{array}{l}\text { Std. } \\
\text { Error }\end{array}$ & Beta & & \\
\hline (Constant) & $-18,461$ & 1,014 & & $-18,201$ & ,000 \\
\hline $\begin{array}{l}\text { Struktur } \\
\text { Aktiva }\end{array}$ & 1,028 & 151 & ,354 & 6,800 & ,000 \\
\hline $\begin{array}{ll} & \text { Stabilitas } \\
1 & \text { Penjualan }\end{array}$ &,- 058 & ,042 &,- 070 & $-1,383$ & ,174 \\
\hline $\begin{array}{l}\text { Return On } \\
\text { Asset }\end{array}$ & $-1,372$ & ,495 &,- 149 & $-2,771$ & ,008 \\
\hline $\begin{array}{l}\text { Ukuran } \\
\text { Perusahaan }\end{array}$ & 893 & ,049 & 937 & 18,324 & ,000 \\
\hline
\end{tabular}

Sumber : Output SPSS Versi 22 Tahun 2019

Berdasarkan dari hasil output SPSS diatas pada tabel 6, dapat disimpulkan sebagai berikut:

1) Pengaruh Struktur Aktiva (X1) terhadap Debt to Equity Ratio (Y), diperoleh nilai signifikan sebesar $0,000<0,05$ dengan $t_{\text {hitung }}$ $6,800>t_{\text {tabel }} 2,015$. Maka Ho ditolak dan Ha diterima, yang berarti Struktur Aktiva berpengaruh signifikan terhadap Debt to Equity Ratio pada PT. Bintan Jaya Sakti. Struktur Aktiva benilai positif yang artinya semakin tinggi aktiva yang dimiliki oleh perusahaan semakin tinggi Debt to Equity Ratio yang dihasilkan perusahaan. Jadi dapat disimpulkan $\mathrm{H} 1$ dapat diterima.

2) Pengaruh Stabilitas Penjualan (X2) terhadap Debt to Equity Ratio (Y), diperoleh nilai signifikan sebesar $0,174>0,05$ dengan $t_{\text {hitung }}-1,383>t_{\text {tabel }}-2,015$. Maka Ho diterima dan Ha ditolak, sehingga dapat disimpulkan bahwa secara parsial Stabilitas Penjualan tidak berpengaruh dan tidak signifikan terhadap Debt to Equity Ratio pada PT. Bintan Jaya Sakti. Sehingga H2 ditolak.

3) Pengaruh Return On Assets (X3) terhadap Debt to Equity Ratio (Y), diperoleh nilai signifikan sebesar $0,008<0,05$ dengan $t_{\text {hitung }-}$ $2,771<\mathrm{t}_{\text {tabel }}-2,015$. Maka Ho ditolak dan $\mathrm{Ha}$ diterima, sehingga dapat disimpulkan bahwa secara parsial Return On Assets berpengaruh negative dan signifikan terhadap Debt to Equity Ratio pada PT. Bintan Gas Jaya Sakti. Hubungan negatif ini menunjukkan bahwa jika variabel Return On Asset mengalami kenaikan maka menyebabkan penurunan terhadap variable Debt to Equity Ratio begitu pula sebaliknya. Sehingga, H3 dapat diterima.

4) Pengaruh Ukuran Perusahaan (X4) terhadap Debt to Equity Ratio (Y), diperoleh nilai signifikan sebesar $0,000<0,05$ dengan $\mathrm{t}_{\text {hitung }}$ 18,324 $>\mathrm{t}_{\text {tabel }}$ 2,015. Maka Ho ditolak dan Ha diterima, sehingga dapat disimpulkan bahwa secara parsial Ukuran Perusahaan berpengaruh positif dan signifikan terhadap Debt to Equity Ratio. Sehingga dapat ditarik kesimpulan bahwa $\mathrm{H} 4$ dapat diterima.

4. Hasil Uji koefisien Determinasi (Uji Adjusted R2)

Tabel 7

Hasil Uji R2 
Model Summary

\begin{tabular}{|l|r|r|r|r|}
\hline Model & $\mathrm{R}$ & $\mathrm{R}$ Square & \multicolumn{1}{c|}{$\begin{array}{c}\text { Adjusted } \mathrm{R} \\
\text { Square }\end{array}$} & $\begin{array}{l}\text { Std. Error of the } \\
\text { Estimate }\end{array}$ \\
\hline 1 &, $946^{\mathrm{a}}$ &, 895 &, 885 &, 03027 \\
\hline
\end{tabular}

a. Predictors: (Constant), Ukuran Perusahaan, Stabilitas Penjualan, Struktur Aktiva, Return On Asset

b. Dependent Variable: Debt to Equity Ratio

Sumber : Output SPSS Versi 22 Tahun 2019

Dari tabel 7 diatas, diperoleh nilai determinasi Adjusted R Square sebesar 0,885 atau $88,5 \%$. Hal ini menunjukkan bahwa persentase pengaruh Struktur Aktiva, Stabilitas Penjualan, Return On Assets, dan Ukuran Perusahaan terhadap Debt to Equity Ratio sebesar $88,5 \%$ sedangkan sisanya $11,5 \%$ dipengaruhi oleh variable lain yang tidak diteliti dalam penelitian ini.

\section{Hasil Uji Moderated Regression}

\section{Analysis}

Dalam penelitian ini variabel moderating yang digunakan adalah Ukuran Perusahaan.

$$
\begin{aligned}
& Y 1=a+b 1 X 1+b 4 Z+b 5(X 1 Z)+e \\
& Y 2=a+b 2 X 2+b 4 Z+b 6(X 2 Z)+e \\
& Y 3=a+b 3 X 3+b 4 Z+b 7(X 3 Z)+e
\end{aligned}
$$

1) Output Moderated Regression Analysis (MRA) Persamaan I

\begin{tabular}{|c|c|c|c|c|c|}
\hline \multicolumn{6}{|c|}{ Coefficients $^{a}$} \\
\hline \multirow[t]{2}{*}{ Model } & \multicolumn{2}{|c|}{$\begin{array}{c}\text { Unstandardized } \\
\text { Coefficients }\end{array}$} & \multirow{2}{*}{$\begin{array}{c}\begin{array}{c}\text { Standardized } \\
\text { Coefficients }\end{array} \\
\text { Beta }\end{array}$} & \multirow[t]{2}{*}{$t$} & \multirow[t]{2}{*}{ Sig. } \\
\hline & B & $\begin{array}{l}\text { Std. } \\
\text { Error }\end{array}$ & & & \\
\hline (Constant) & $-15,104$ & 1,404 & & $-10,759$ &, 000 \\
\hline Struktur Aktiva & $-3,086$ & 1,521 & $-1,062$ & $-2,029$ &, 049 \\
\hline Ukuran & .727 &, 070 & ,763 & 10,462 &, 000 \\
\hline 1 Perusahaan &,$r<t$ & oro & & & \\
\hline Struktur & & & & & \\
\hline Aktiva*Ukuran & ,202 &, 077 & 1,374 & 2,629 &, 012 \\
\hline Perusahaan & & & & & \\
\hline
\end{tabular}

Tabel 8

Tabel Uji MRA Persamaan I a. Dependent Variable: Debt to Equity Ratio

Sumber : Output SPSS Versi 22 Tahun 2019

Berdasarkan tabel 8 diatas, pada uji t pada persamaan 1 diatas menunjukkan bahwa variabel Ukuran Perusahaan merupakan variabel moderating dalam hubungan antara Struktur Aktiva terhadap Debt to Equity Ratio pada PT. Bintan Gas Jaya Sakti. Hal ini tebukti pada nilai thitung 2,2621 diperoleh nilai signifikansi variable interaksi antara Struktur Aktiva dan Ukuran Perusahaan sebesar 0,012 lebih kecil dari 0,05 . Sedangkan nilai $t_{\text {hitung }}$ sebesar 2,629>t tabel 2,015 dengan nilai signigfikansi $0,012<0,05$. Hal ini menunjukkan bahwa Ukuran Perusahaan merupakan variabel moderating yang dapat memperkuat antara Struktur Aktiva terhadap Debt to Equity Ratio. Sehingga ukuran perusahaan dapat memoderasi pengaruh struktur aset terhadap struktur modal perusahaan. Jadi dapat disimpulkan hipotesis H5 dapat diterima.

2) Output Moderated Regression Analysis (MRA) Persamaan II

Tabel 9

Tabel Uji MRA Persamaan II 


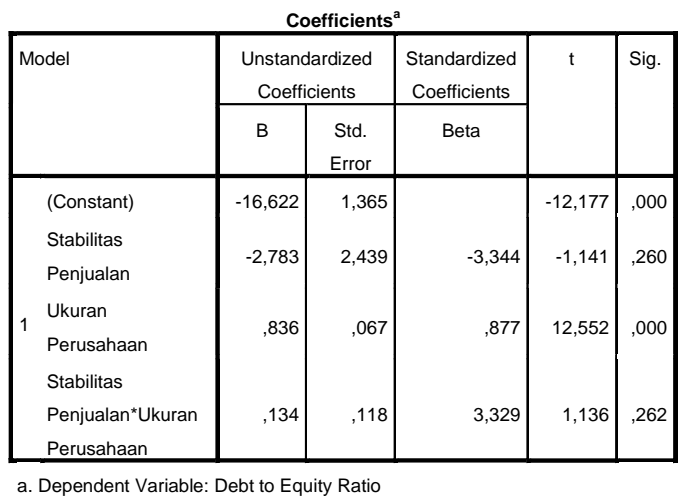

Sumber : Output SPSS Versi 22 Tahun 2019

Berdasarkan tabel 9 diatas, diketahui hasil pengujian $t$ pada persamaan 2 diatas menunjukkan nilai $t_{\text {hitung }}-1,141<\mathrm{t}_{\text {tabel }}-2,015$ dan nilai signifikansi $0,262>0,05$. Hal ini menunjukkan bahwa Ukuran Perusahaan bukan merupakan variabel moderating dan tidak dapat memperkuat atau memperlemah hubungan antara stabilitas penjualan terhadap Debt to Equity Ratio. Sehingga dapat disimpulkan bahwa hipotesis H6 ditolak.

3) Output Moderated Regression Analysis (MRA) Persamaan III

Tabel 10

Tabel Uji MRA Persamaan III

\begin{tabular}{|c|c|c|c|c|c|}
\hline & & efficient & & & \\
\hline \multirow[t]{2}{*}{ Model } & \multicolumn{2}{|c|}{$\begin{array}{l}\text { Unstandardized } \\
\text { Coefficients }\end{array}$} & \multirow{2}{*}{$\begin{array}{c}\begin{array}{c}\text { Standardized } \\
\text { Coefficients }\end{array} \\
\text { Beta }\end{array}$} & \multirow[t]{2}{*}{$t$} & \multirow[t]{2}{*}{ Sig. } \\
\hline & B & $\begin{array}{l}\text { Std. } \\
\text { Error }\end{array}$ & & & \\
\hline (Constant) & $-16,240$ & 1,376 & & $-11,801$ & ,000 \\
\hline Return On Asset & $-3,863$ & 1,760 &,- 418 & $-2,195$ & ,033 \\
\hline Ukuran & & & & & \\
\hline 1 Perusahaan & , & , & , 857 & 12,131 & 然, \\
\hline Return on & & & & & \\
\hline AssetUkuran & ,198 & ,093 & ,414 & 2,135 & ,038 \\
\hline Perusahaan & & & & & \\
\hline
\end{tabular}

Sumber : Output SPSS Versi 22 Tahun 2019

Berdasarkan tabel 10 diatas, diketahui hasil pengujiam $\mathrm{t}$ pada persamaan 3 diatas menunjukkan nilai $t_{\text {hitung }} 2,135>t_{\text {tabel }} 2,015$ dan nilai signifikansi $0,038>0,05$. Hal ini menunjukkan bahwa Ukuran Perusahaan merupakan variabel moderating dan dapat memperkuat atau memperlemah hubungan antara Return On Asset terhadap Debt to Equity Ratio. Sehingga dapat disimpulkan bahwa hipotesis $\mathrm{H} 7$ dapat diterima.

\section{Pembahasan Hasil Penelitian}

\section{Pembahasan Secara Parsial (uji t)}

Berdasarkan uji hipotesis yang telah dilakukan, maka dapat ditafsirkan hasil penelitian sebagai berikut:

a. Pengaruh Struktur Aktiva terhadap Debt to Equity Ratio pada PT. Bintan Gas Jaya Sakti

Pengaruh Struktur Aktiva (X1) terhadap Debt to Equity Ratio (Y), diperoleh nilai signifikan sebesar $0,000<0,05$ dengan thitung 6,800 > ttabel 2,015. Maka Ho ditolak dan Ha diterima, yang berarti Struktur Aktiva berpengaruh signifikan terhadap Debt to Equity Ratio pada PT. Bintan Jaya Sakti. Hasil penelitian ini sesuai dengan teori yang telah dijelaskan sebelumnya yang menunjukkan bahwa dengan meningkatnya Debt to Equity Ratio maka anak diikuti dengan meningkatnya struktur aktiva. Hal tersebut menunjukkan bahwa perusahaan dengan struktur aktiva yang lebih besar, cenderung lebih memilih untuk membiayai setiap aktivitas perusahaannya melalui modal eksternal daripada modal internal.

b. Pengaruh Stabilitas Penjualan terhadap Debt to Equity Ratio pada PT. Bintan Gas Jaya Sakti 
Pengaruh Stabilitas Penjualan (X2) terhadap Debt to Equity Ratio (Y), diperoleh nilai signifikan sebesar 0,174 > 0,05 dengan $t_{\text {hitung }}-1,383>t_{\text {tabel }}-2,015$. Maka Ho diterima dan Ha ditolak, sehingga dapat disimpulkan bahwa secara parsial Stabilitas Penjualan tidak berpengaruh dan tidak signifikan terhadap Debt to Equity Ratio pada PT. Bintan Jaya Sakti. Perusahaan yang memiliki aliran kas yang relatif stabil pula, maka dapat menggunakan utang yang lebih besar daripada perusahaan yang dengan penjualan yang tidak stabil. Tidak signifikannya stabilitas penjualan dapat disebabkan karena penjualan yang stabil tidak menjamin perusahaan tersebut mempunyai arus kas yang cukup untuk membayar bunga dan beban tetapnya. Arus kas yang dimaksud adalah penjualan barang bukan penjualan aktiva tetap atau saham. Sehingga perusahaan tidak berani untuk mengambil utang dalam jumlah yang cukup besar karena akan meningkatkan resiko kebangkrutan. Stabilitas penjualan tidak stabil kemungkinan perusahaan untuk membayar bunga dan beban tetapnya menjadi terhambat. Hal ini didukung oleh peneliti terdahulu yang dilakukan oleh (Vitriasari, 2012) yang menyatakan bahwa stabilitas penjualan tidak berpengaruh terhadap struktur modal.

c. Pengaruh Stabilitas Penjualan terhadap

Debt to Equity Ratio pada PT. Bintan Gas Jaya Sakti

Pengaruh Return On Assets (X3) terhadap Debt to Equity Ratio (Y), diperoleh nilai signifikan sebesar $0,008<0,05$ dengan $t_{\text {hitung }}$ $2,771<t_{\text {tabel }}-2,015$. Maka Ho ditolak dan Ha diterima, sehingga dapat disimpulkan bahwa secara parsial Return On Assets berpengaruh negative dan signifikan terhadap Debt to Equity Ratio pada PT. Bintan Gas Jaya Sakti. Hasil penelitian ini mengungkapkan bahwa dengan meningkatnya Return On Assets maka akan diikuti dengan menurunnya Debt to Equity Ratio. Dalam penelitian ini menyatakan bahwa variabel Return On Assets berpengaruh negatif terhadap Debt to Equity Ratio. Dengan kata lain, hal tersebut menunjukkan bahwa perusahaan dengan Return On Assets yang tinggi (profitable) cenderung menggunakan utang yang relatif kecil. Sedangkan perusahaan dengan Return On Assets yang rendah, justru cenderung memenuhi kebutuhan modalnya melalui utang. Hal tersebut terjadi karena perusahaan dengan tingkat pengembalian yang tinggi, berarti perusahaan tersebut menghasilkan laba ditahan yang cukup untuk membiayai aktivitas perusahaannya. Oleh karena itu perusahaan dengan Return On Assets yang tinggi kurang membutuhkan tambahan modal eksternal.

d. Pengaruh Ukuran Perusahaan terhadap

Debt to Equity Ratio_pada PT. Bintan Gas Jaya Sakti

Pengaruh Ukuran Perusahaan (X4) terhadap Debt to Equity Ratio (Y), diperoleh nilai signifikan sebesar $0,000<0,05$ dengan $\mathrm{t}_{\text {hitung }}$ 18,324 $>\mathrm{t}_{\text {tabel }}$ 2,015. Maka Ho ditolak dan Ha diterima, sehingga dapat disimpulkan 
bahwa secara parsial Ukuran Perusahaan berpengaruh positif dan signifikan terhadap Debt to Equity Ratio. Penelitian ini menunjukkan hasil bahwa semakin besar nilai ukuran perusahaan maka semakin besar juga Debt to Equity Ratio pada perusahaan. Perusahaan yang besar cenderung terdiversivikasi sehingga menurunkan resiko kebangkrutan. Ukuran perusahaan sering dijadikan indikator bagi kemungkinan terjadinya kebangkrutan bagi suatu perusahaan, dimana perusahaan dengan ukuran lebih besar dipandang lebih mampu mengahadapi krisis dalam menjalankan usahanya. Hal ini akan mempermudah perusahaan dengan ukuran besar untuk memperoleh pinjaman dari kreditur. Apabila semakin besar ukuran perusahaan maka semakin besar juga Debt to Equity Ratio dalam perusahaan.

\section{Pembahasan Secara Moderating} Menggunakan Moderated Regression Analysis (MRA)

a. Pengaruh Struktur Aktiva terhadap Debt to Equity Ratio dengan Ukuran Perusahaan sebagai Variabel Moderating pada PT. Bintan Gas Jaya Sakti

Pada Uji MRA Persamaan 1, menunjukkan nilai $t_{\text {hitung }}$ 2,2621 diperoleh nilai signifikansi variable interaksi antara Struktur Aktiva dan Ukuran Perusahaan sebesar 0,012 lebih kecil dari 0,05. Sedangkan nilai $t_{\text {hitung }}$ sebesar 2,629 $>t_{\text {tabel }}$ 2,015 dengan nilai signigfikansi 0,012 <0,05.
Hal ini menunjukkan bahwa Ukuran Perusahaan merupakan variabel moderating yang dapat memperkuat antara Struktur Aktiva terhadap Debt to Equity Ratio. Menurut penelitian yang dilakukan oleh (Yanuar Cristie, 2015) perusahaan yang memiliki ukuran perusahaan yang besar cenderung memiliki total aset yang besar. Maka semakin besar ukuran perusahaan tersebut semakin besar pula struktur asetnya. Hal ini dikarenakan perusahaan yang memiliki komposisi aset tetap yang besar memiliki akses yang mudah untuk memperoleh pinjaman, aset tersebut nantinya dapat digunakan oleh perusahaan sebagai jaminan untuk memperoleh sumber dana eksternal (utang). Semakin besar struktur aset maka perusahaan memiliki peluang yang besar untuk memperoleh utang. Sehingga ukuran perusahaan dapat memoderasi pengaruh struktur aset terhadap struktur modal perusahaan pada PT. Bintan Gas Jaya Sakti.

b. Pengaruh Stabilitas Penjualan terhadap Debt to Equity Ratio dengan Ukuran Perusahaan sebagai Variabel Moderating pada PT. Bintan Gas Jaya Sakti

Hasil pengujian t pada persamaan 2 diatas menunjukkan nilai $t_{\text {hitung }}-1,141<\mathrm{t}_{\text {tabel }}-2,015$ dan nilai signifikansi $0,262>0,05$. Hal ini menunjukkan bahwa Ukuran Perusahaan bukan merupakan variabel moderating dan tidak dapat memperkuat atau memperlemah 
hubungan antara stabilitas penjualan terhadap Debt to Equity Ratio. Menurut (Houston, 2014) secara garis besar perusahaan dengan penjualan yang stabil cenderung menggunakan utang lebih banyak. Namun, hasil penelitian yang dilakukan bahwa Ukuran perusahaan tidak memperkuat pengaruh Stabilitas penjualan terhadap Debt to Equity Ratio Kondisi ini menunjukkan bahwa dalam penentuan utang pada perusahaan tidak bergantung kepada ukuran perusahaan, artinya penentuan Debt to Equity Ratio perusahaan dapat dilakukan dengan optimal baik pada perusahaan besar ataupun perusahaan kecil, hal ini disebabkan karena perusahaan harus menyesuaikan kondisi perusahaan yang dihadapkan pada suatu keputusan yang mengharuskan perusahaan untuk menggunakan pendanaan internal maupun eksternal yang mana tingkat stabilitas penjualan yang tinggi tidak menjadi dasar untuk para investor memilih perusahaan untuk menanamkan modalnya. Investor tidak melihat besar kecilnya suatu perusahaan yang diukur dari jumlah aset. Selain itu meskipun penggunaan utang pada perusahaan tinggi dapat meningkatkan laba, hal ini belum tentu berguna apabila terjadi kenaikan kenaikan harga pokok penjualan dan biaya operasi yang sama atau bahkan melebih presentase keuntungan penghematan pajak yang didapat dari penggunaan utang.

c. Pengaruh Return On Asset terhadap Debt to Equity Ratio dengan Ukuran Perusahaan sebagai Variabel Moderating pada PT. Bintan Gas Jaya Sakti

Hasil pengujian t pada persamaan 3 diatas menunjukkan nilai $t_{\text {hitung }} 2,135<t_{\text {tabel }} 2,015$ dan nilai signifikansi $0,038>0,05$. Hal ini menunjukkan bahwa Ukuran Perusahaan merupakan variabel moderating dan dapat memperkuat hubungan antara Return On Asset terhadap Debt to Equity Ratio. Menurut penelitian yang dilakukan oleh (Suherman, 2019) semakin meningkatnya Return On Asset suatu perusahaan, mencerminkan kinerja perusahaan yang baik sehingga para investor akan tertarik untuk menanamkan modalnya. Hal ini akan berdampak terhadap naiknya ukuran perusahaan. Ukuran perusahaan yang besar menjadi daya tarik para investor untuk menanamkan modalnya. Ukuran perusahaan yang besar dinilai mampu menghasilkan Return On Asset yang besar pula.

\section{Analisis Koefisien Determinasi $\left(\mathbf{R}^{2}\right)$}

Koefisien determinasi $\left(\mathrm{R}^{2}\right)$ berguna untuk mengetahui seberapa besar peran variabel independen secara bersama-sama menjelaskan pengaruh yang terjadi terhadap variabel dependen. Hasil uji koefisien determinasi diperoleh nilai determinasi Adjusted $R$ Square sebesar 0,885 atau 88,5\%. Hal ini menunjukkan bahwa persentase pengaruh Struktur Aktiva, Stabilitas Penjualan, Return On Assets, dan Ukuran Perusahaan terhadap Debt to Equity Ratio sebesar $88,5 \%$ sedangkan sisanya $11,5 \%$ 
dipengaruhi oleh variable lain yang tidak diteliti dalam penelitian ini. Variabel yang tidak di telili dalam penelitian ini antara lain leverage keuangan, pajak, pengendalian, sikap manajemen, kondisi pasar, dll.

\section{PENUTUP}

Adapun yang akan dibahas pada bagian penutup dalam penelitian ini sebagai berikut:

\section{Kesimpulan}

1. Hasil pengujian secara parsial (uji t) menunjukkan bahwa pengaruh Struktur Aktiva secara parsial berpengaruh signifikan terhadap Debt to Equity Ratio pada PT. Bintan Gas Jaya Sakti. Hal ini terbukti diperoleh nilai signifikan sebesar $0,000<0,05$ dengan $t_{\text {hitung }} 6,800>t_{\text {tabel }}$ 2,015. Maka Ho ditolak dan Ha diterima, yang berarti Struktur Aktiva berpengaruh signifikan terhadap Debt to Equity Ratio pada PT. Bintan Gas Jaya Sakti. Sehingga hipotesis 1 dapat diterima.

2. Berdasarkan hasil pengujian pada uji $t$, menunjukkan bahwa pengaruh Stabilitas Penjualan secara parsial tidak berpengaruh dan tidak signifikan terhadap Debt to Equity Ratio. Hal ini terbukti diperoleh nilai signifikan sebesar $0,174>0,05$ dengan $t_{\text {hitung }}-1,383>t_{\text {tabel }}-2,015$. Maka Ho diterima dan Ha ditolak, artinya bahwa secara parsial Stabilitas Penjualan tidak berpengaruh dan tidak signifikan terhadap Debt to Equity Ratio pada PT. Bintan Gas Jaya Sakti. Sehingga Hipotesis 2 ditolak.
3. Pada pengujian uji t menunjukkan bahwa Return On Assets berpengaruh signifikan terhadap Debt to Equity Ratio. Hal ini terbukti, diperolehnya nilai signifikan sebesar $0,008<0,05$ dengan $_{\text {hitung }}-2,771<$ $t_{\text {tabel }}$-2,015. Maka Ho ditolak dan Ha diterima, diartikan bahwa Return On Assets berpengaruh negatif terhadap Debt to Equity Ratio PT. Bintan Gas Jaya Sakti. Sehingga Hipotesis 3 dapat diterima.

4. Pada pengujian uji t menunjukkan bahwa Ukuran Perusahaan berpengaruh signifikan terhadap Debt to Equity Ratio. Hal ini terbukti, diperolehnya nilai signifikan sebesar $0,000<0,05$ dengan $t_{\text {hitung }} 18,324>t_{\text {tabel }} 2,015$. Penelitian ini menunjukkan hasil positif bahwa semakin besar nilai ukuran perusahaan maka semakin besar juga Debt to Equity Ratio pada perusahaan. Sehingga Hipotesis 4 dapat diterima.

5. Pada uji determinasi Adjusted $R$ Square diperoleh nilai sebesar 0,885 atau 88,5\%. Hal ini menunjukkan bahwa persentase pengaruh Struktur Aktiva, Stabilitas Penjualan, Return On Assets, dan Ukuran Perusahaan terhadap Debt to Equity Ratio sebesar $88,5 \%$ sedangkan sisanya $11,5 \%$ dipengaruhi oleh variable lain yang tidak diteliti dalam penelitian ini.

6. Pada pengujian moderating, menunjukkan bahwa variabel Ukuran Perusahaan merupakan variabel moderating dalam hubungan antara Struktur Aktiva terhadap Debt to Equity Ratio. Hal ini tebukti pada 
nilai thitung 2,2621 diperoleh nilai signifikansi variable interaksi antara Struktur Aktiva dan Ukuran Perusahaan sebesar 0,012 lebih kecil dari 0,05. Sedangkan nilai $t_{\text {hitung }}$ sebesar 2,629 $>t_{\text {tabel }}$ 2,015 dengan nilai signigfikansi 0,012 < 0,05. Hal ini menunjukkan bahwa Ukuran Perusahaan merupakan variabel moderating yang dapat memperkuat antara Struktur Aktiva terhadap Debt to Equity Ratio pada PT. Bintan Gas Jaya Sakti. Sehingga Hipotesis 5 dapat diterima.

7. Pada pengujian moderating, menunjukkan bahwa variabel Ukuran Perusahaan bukan merupakan variabel moderating dalam hubungan antara Stabilitas Penjualan terhadap Debt to Equity Ratio. Hal tersebut terbukti pada nilai $\mathrm{t}_{\text {hitung }}-1,141<\mathrm{t}_{\text {tabel }}-$ 2,015 dan nilai signifikansi 0,262>0,05. Hal ini menunjukkan bahwa Ukuran Perusahaan bukan merupakan variabel moderating dan tidak dapat memperkuat atau memperlemah hubungan antara stabilitas penjualan terhadap Debt to Equity Ratio pada PT. Bintan Gas Jaya Sakti. Sehingga Hipotesis 6 ditolak.

8. Hasil moderating menunjukkan bahwa variabel Ukuran Perusahaan merupakan variabel moderating dalam hubungan antara Return On Asset terhadap Debt to Equity Ratio. Hal tersebut terbukti pada nilai $t_{\text {hitung }} 2,135<t_{\text {tabel }} 2,015$ dan nilai signifikansi $0,038>0,05$. Hal ini menunjukkan bahwa Ukuran Perusahaan merupakan variabel moderating dan dapat memperkuat hubungan antara Return On Asset terhadap Debt to Equity Ratio pada PT. Bintan Gas Jaya Sakti. Sehingga Hipotesis 7 dapat diterima.

\section{Saran}

1. Dari hasil penelitian yang dilakukan pada PT. Bintan Gas Jaya Sakti diharapkan dapat meningkatkan struktur aktiva perusahaan melalui penggunaan utang pada perusahaan.

2. Dari hasil penelitian yang dilakukan pada PT. Bintan Gas Jaya Sakti diharapkan dapat meningkatkan stabilitas penjualan perusahaan melalui penggunaan utang pada perusahaan.

3. Dari hasil penelitian yang dilakukan pada PT. Bintan Gas Jaya Sakti diharapkan dapat meningkatkan return on asset perusahaan melalui penggunaan utang pada perusahaan.

4. Dari hasil penelitian yang dilakukan pada PT. Bintan Gas Jaya Sakti diharapkan dapat memperhatikan ukuran perusahaan dalam meningkatkan Struktur Aktiva dan menjaga keseimbangan antara Ukuran perusahaan, struktur aktiva dan debt to equity ratio sesuai dengan kondisi, dimana kondisi pada perusahaan ini ukuran perusahaan memperkuat hubungan antara struktur aktiva terhadap debt to equity ratio.

5. Dari hasil penelitian yang dilakukan pada PT. Bintan Gas Jaya Sakti diharapkan 
dapat memperhatikan ukuran perusahaan dalam meningkatkan stabilitas penjualan dan menjaga keseimbangan antara Ukuran perusahaan, stabilitas penjualan dan debt to equity ratio sesuai dengan kondisi, dimana kondisi pada perusahaan ini ukuran perusahaan tidak mampu memperkuat atau memperlemah hubungan antara stabilitas penjualan terhadap debt to equity ratio.

6. Dari hasil penelitian yang dilakukan pada PT. Bintan Gas Jaya Sakti diharapkan dapat memperhatikan ukuran perusahaan dalam meningkatkan return on asset dan menjaga keseimbangan antara Ukuran perusahaan, stabilitas penjualan dan debt to equity ratio sesuai dengan kondisi, dimana kondisi pada perusahaan ini ukuran perusahaan mampu memperkuat hubungan antara return on asset terhadap debt to equity ratio.

7. Penelitian selanjutnya disarankan untuk melakukan penelitian di luar variabel independen yang digunakan dalam penelitian ini ataupun mengkombinasikan salah satu variabel atau menambahkan variabel lain.

8. Penelitian selanjutnya diharapkan menggunakan sampel yang lebih banyak dan menggunakan kurun waktu yang berbeda dengan penelitian ini. Dalam penelitian ini menggunakan data perbulan periode 2015-2018.

\section{DAFTAR PUSTAKA}

Batubara, R. A. P., Topowijono, \& Z. A., Z. (2015). Pengaruh Struktur Aktiva, Ukuran Perusahaan, dan Profitabilitas terhadap Struktur Modal (Studi pada Perusahaan Makanan dan Minuman yang Terdaftar di Bursa Efek Indonesia Tahun 2012-2015). Jurnal Administrasi Bisnis (JAB), 50(4), 1-9. Retrieved from http://administrasibisnis.studentjournal. ub.ac.id/index.php/jab/article/view/202 4

Hery. (2015). Analisis Laporan Keuangan Pendekatan Rasio Keuangan. Yogyakarta: PT Buku Seru.

Houston, B. dan. (2014). Dasar-Dasar Manajemen Keuangan (Sebelas). Jakarta Selatan: Salemba Empat.

Kasmir. (2015). Analisis Laporan Keuangan. (N. Lestari, Ed.). Yogyakarta: QUADRANT.

Musthafa. (2017). Manajemen Keuangan. Yogyakarta: CV Andi Offset.

Nisfianti, R. (2017). Pengaruh Struktur Aktiva Dan Profitabilitas Terhadap Struktur Modal: Ukuran Perusahaan Sebagai Pemoderasi, 6 .

Sartono, A. (2010). Manajemen Keuangan Teori dan Aplikasi (Keempat). Yogyakarta: BPFE.

Siti Nurlaela, S. A. M. D. (2017). Pengaruh Ukuran Perusahaan, Pertumbuhan Asset, Profitabilitas Dan Pertumbuhan Penjualan Terhadap Struktur Modal Perusahaan Cosmetics and Household Di Bursa Efek Indonesia. Jurnal Akuntansi Dan Pajak, 18(01), 16-30. https://doi.org/10.29040/jap.v18i01.81

Suherman, R. P. dan U. M. (2019). MIX: Jurnal Ilmiah Manajemen, Volume 9, No. 2, Juni 2019, 9(2), 369-381.

Suweta, N. M. N. P. D. (2016). Pengaruh Pertumbuhan Perjualan, Struktur Aktiva, dan Pertumbuhan Aktiva Terhadap Struktur Modal. E-Jurnal Manajemen Unud, 5(8), 5172-5199. https://doi.org/ISSN : 2302-8912

Syamsuddin, L. (2011). Manajemen Keuangan Perusahaan. Jakarta: PT RajaGrafindo Persada.

Vitriasari, R. iin I. (2012). Pengaruh Stabilitas Penjualan, Struktur Aktiva 
DanTingkat Pertumbuhan Terhadap Struktur Modal ( Studi Empiris

Terhadap Perusahaan Real Estate and

Property yang Terdaftar di BEI Tahun 2007-2009 ) The Influence of Stability of Sale, Asset Structure and Gr, 1-19.
Yanuar Cristie, F. (2015). Analisis FaktorFaktor yang Mempengaruhi Struktur Modal, dengan Ukuran Perusahaan sebagai Variabel Moderating. Skripsi (Unpublished), 4, 1-9. 